\title{
Pendidikan Kesehatan Mengenai Pencegahan Perilaku Seksual melalui Peningkatan Asertivitas pada Remaja Putri
}

\author{
Visi Aurora Amartha, Iffa Fathimiyah, Laili Rahayuwati, Imas Rafiyah \\ Fakultas Keperawatan, Universitas Padjadjaran \\ Email : visiaurora.VA@gmail.com
}

\begin{abstract}
Abstrak
Pacaran remaja meningkat sejalan dengan meningkatnya kejadian pemaksaan perilaku seksual pranikah dalam pacaran, kehamilan diluar nikah dan aborsi. Menurut KemenPPPA (2017), penanganan dan pencegahan terhadap pemaksaan perilaku seksual selama pacaran dapat dilakukan dengan bersikap asertif terkait seksual. Oleh karena itu, perlu dilakukan pencegahan melalui peningkatan asertivitas seksual pada remaja putri khususnya di SMK Baabul Kamil Jatinangor yang memiliki remaja putri dengan pengalaman perilaku seksual dalam kategori resiko tinggi. Metode yang digunakan dalam kegiatan Pengabdian pada masyarakat ini adalah dengan pendidikan masyarakat kepada 65 remaja putri di SMK Baabul Kamil Jatinangor. Materi yang disampaikan yaitu perilaku seksual dan asertivitas seksual. Sebelum dilakukan penyuluhan, penyuluh menanyakan pemahaman siswa mengenai perilaku seksual. Penyuluhan dilaksanakan diruang kelas dengan durasi waktu 25 menit dimana selama 10 menit untuk pemaparan materi dan 15 menit untuk diskusi bagi peserta yang ingin mengajukan pertanyaan dan evaluasi. Hasil penyuluhan didapatkan peserta antusias terhadap materi penyuluhan, tidak ada peserta yang meninggalkan tempat penyuluhan sebelum acara berakhir, peserta mengajukan pertanyaan dan menjawab seluruh pertanyaan dari penyuluh dengan benar. Peserta mampu mengetahui terkait perilaku seksual dan asertivitas seksual.
\end{abstract}

Kata kunci: Asertivitas, perilaku seksual pranikah, remaja

\begin{abstract}
Dating adolescence increased in line with increased of sexual coercion incidence in dating, premarital pregnancy, and abortion. According to KemenPPPA (2017), the handling and prevention of sexual coercion incidence in dating can be done by being assertiveness related to sexual. Therefore, prevention needs to be done through improving sexual assertiveness on adolescent girls especially in SMK Baabul Kamil Jatinangor who have adolescent girls with experience of sexual behavior in high risk category. The method used in this Community Service activity was community education to 65 girls at SMK Baabul Kamil Jatinangor. The material presented were sexual behavior and sexual assertiveness. Prior to the health education, presenters asked students' understanding of sexual behavior. The health education was conducted in the classroom with a duration of 25 minutes, 10 minutes for material presentation and 15 minutes for discussion for participants who wanted to ask questions and evaluation. The results were given by enthusiastic participants to the extension materials, none of the participants who left the counseling site before the event ended, the participants asked questions and answered all questions from the extension officer correctly. Participants were able to know related sexual behavior and sexual assertiveness.
\end{abstract}

Keywords: Adolescence, assertiveness, premarital sexual behavior. 


\section{Pendahuluan}

Perilaku seksual merupakan segala tindakan yang didorong oleh hasrat seksual terhadap lawan jenis maupun dengan sesama jenis (Sarwono, 2016). Adapun bentuk perilaku seksual salah satunya yaitu pacaran. Pacaran sudah menjadi hal yang lumrah dilakukan oleh remaja pada saat ini. Barter, McCarry, Berridge, dan Evans (2009) menunjukkan bahwa $88 \%$ remaja di Inggris pernah terlibat dalam hubungan pacaran. Berdasarkan survei Badan Pusat Statistik [BPS], Badan Kependudukan dan Keluarga Berencana Nasional [BKKBN], Kementerian Kesehatan [Kemenkes], \& ICF International (2013), menunjukkan bahwa remaja Indonesia yang pernah pacaran mencapai $85 \%$. Dengan demikian, dapat disimpulkan bahwa pacaran remaja menunjukkan angka yang tinggi tidak hanya di luar negeri melainkan juga di dalam negeri.

Di Indonesia, individu memulai pacaran pertama kali pada usia remaja, dimana pada perempuan sekitar 33,3 \% pertama kali pacaran di usia 15-17 tahun dan 34,5\% pada laki-laki saat mereka belum berusia 15 tahun (Kemenkes, 2015). Mayoritas remaja melakukan perilaku seksual pranikah pertama kali pada usia 15-18 tahun yaitu mayoritas pada usia Sekolah Menengah Atas (SMA) atau sederajat lainnya (Soetiningsih, 2008). Hal ini didukung oleh Freud (Hidayat, 2008) bahwa pada masa ini anak mulai mengalami ketertarikan pada lawan jenis dan mencari suatu pola untuk memuaskan dorongan genitalnya.

Adapun tahapan perilaku seksual pada masa pacaran dimulai dari berpegangan tangan, berpelukan, necking, meraba bagian tubuh yang sensitif, petting, oral seks, hingga sexual intercourse (Mutiara, Maria, \& Karwati, 2008). Perilaku seksual pranikah dapat menimbulkan dampak negatif setelahnya seperti Kehamilan Tidak Diinginkan (KTD) hingga aborsi. Pacaran dan perilaku seksual berkaitan erat satu sama lain. Berpacaran pada usia remaja, dikhawatirkan belum memiliki keterampilan hidup yang mumpuni sehingga kelompok remaja memiliki perilaku pacaran yang tidak sehat (Kemenkes, 2015). Hal ini didukung dengan angka kekerasan dalam pacaran bagi perempuan yang belum menikah yang cukup mengkhawatirkan. Menurut Catatan Tahunan Komnas Perempuan Tahun 2018 pertanggal 7 Maret 2018, didapatkan bahwa pelaku kekerasan seksual di ranah personal yang paling banyak dilaporkan yaitu pacar sebanyak 1.528 orang, diikuti ayah kandung sebanyak 425 orang, dan diperingkat ketiga yaitu paman sebanyak 322 orang. 
Kejadian pemaksaan perilaku seksual lebih banyak dialami oleh perempuan belum menikah pada usia remaja atau SMA sederajat yaitu sebanyak 34,4\% (BPS, 2017). Berdasarkan data dari Pusat Pelayanan Terpadu Pemberdayaan Perempuan dan Anak (P2TP2A), kejadian pemaksaan perilaku seksual di Jawa Barat mencapai angka yang cukup tinggi. Lebih lanjut, Neni Kencanawati selaku kepala BP3AKB Jawa Barat, menyampaikan ada empat wilayah di Jawa Barat dengan kasus pemaksaan perilaku seksual pada anak dan perempuan yang tinggi yaitu Kabupaten Sumedang, Kabupaten Cirebon, Kabupaten Bandung, dan Kabupaten Purwakarta.

Efek dari perilaku seksual atau pacaran sampai dengan kehamilan pada remaja dinyatakan oleh kepala BKKBN di Indonesia, bahwa peningkatan perilaku seksual pranikah membawa dampak yang sangat beresiko salah satunya adalah kehamilan tidak diinginkan sebab dilakukan diluar pernikahan. Setiap tahun terdapat sekitar 1,7 juta kelahiran anak dari perempuan berusia di bawah 24 tahun, yang sebagian adalah KTD (BKKBN, 2016). Komplikasi saat kehamilan dan persalinan merupakan penyebab utama dari kematian pada remaja putri berusia 15-19 tahun di negara berkembang (WHO, 2010). Adapun kehamilan pada remaja memicu untuk terjadinya pernikahan dini. Kepala BKKBN Provinsi Jawa Barat menyatakan bahwa dari tiga provinsi besar di Indonesia, Jawa Barat memiliki angka pernikahan dini remaja terbanyak. Selain itu, ditemukan kejadian kehamilan remaja di luar nikah di Kabupaten Sumedang sebanyak 40,5\% dari seluruh kehamilan usia remaja (Omarsari \& Ratna, 2008).

Penyuluh selaku mahasiswa Keperawatan Universitas Padjadjaran, memiliki peran dalam upaya peningkatan kesehatan di daerah sekitar kampus, terlebih lagi Jatinangor memiliki beberapa perguruan tinggi. Dengan demikian, perilaku seksual mahasiswanya dapat memberikan contoh buruk bagi remaja Jatinangor. Kecamatan Jatinangor sendiri memiliki 12 desa dan desa yang paling banyak dihuni oleh mahasiswa yaitu desa Hegarmanah. Selain itu, pada tahun 2017 di desa Hegarmanah terdapat kejadian pernikahan dini pada tujuh pasangan remaja dimana sebagian besarnya karena kehamilan diluar pernikahan (El Jabar, 2017). Hal ini menunjukkan telah terlihat dampak dari perilaku seksual di Jatinangor, terutama desa Hegarmanah.

Di desa Hegarmanah, terdapat satu-satunya SMA sederajat yang belum pernah mendapatkan pendidikan kesehatan terkait kesehatan reproduksi dan pencegahan seks bebas yaitu SMK Baabul Kamil Jatinangor (Humas FK, 2015). Berdasarkan penuturan 
dari salah satu guru SMK ini, mayoritas siswinya sudah pernah berpacaran. Lebih lanjut, berdasarkan penelitian Fathimiyah (2018) didapatkan hasil bahwa sebagian besar remaja putri di SMK Baabul Kamil Jatinangor memiliki pengalaman perilaku seksual dalam kategori resiko tinggi. Hal tersebut dapat terjadi dimungkinkan karena remaja putri tersebut kurang mendapatkan informasi terkait seksual.

Kurangnya pengetahuan mengenai seksual pada remaja akan meningkatkan perilaku seksual pada remaja tersebut, karena remaja hanya mengetahui cara melakukan perilaku seksual namun tidak mengetahui dampak yang akan dihasilkan (Kumalasari, 2016). Permasalahan serta dampak diatas menunjukkan remaja putri rentan terhadap dampak negatif dari perilaku seksual pranikah. Menurut KemenPPPA (2017), penanganan dan pencegahan bagi perempuan terhadap pemaksaan perilaku seksual selama pacaran dapat dilakukan dengan memberikan dukungan dan meyakinkan untuk berani berkata "tidak" dan menolak setiap tindakan pemaksaan oleh pasangan atau bersikap asertif terkait seksual sehingga dapat terwujud kesejahteraan perempuan.

Asertif terhadap perilaku seksual pranikah atau yang kemudian disebut dengan asertivitas seksual berkaitan tentang kemampuan untuk bersikap tegas mempertahankan hak seksualnya untuk tidak dilecehkan dan dapat mengambil keputusan seksualnya dengan tetap menghargai hak orang lain atau pasangannya, serta mengekspresikan dirinya secara jujur dengan cara yang tepat tanpa perasaan cemas yang mengganggu sehingga mendorong terwujudnya kesejajaran dan persamaan dalam hubungan dengan pasangannya Lubis dan Oriza (2000, dalam Falah, 2009). Menurut Jakubowski \& Lange (1978), terdapat lima karakteristik individu yang memiliki asertivitas, kemudian karakteristik-karakteristik tersebut dikaitkan dengan perilaku seksual pranikah. Karakteristik tersebut yaitu menghormati hak-hak orang lain dan diri sendiri terkait seksual, berani mengemukakan pendapat secara langsung terkait seksual, jujur terkait seksual, memperhatikan situasi dan kondisi terkait seksual, dan memperhatikan bahasa tubuh yang sesuai terkait seksual.

Asertivitas seksual merupakan hal yang penting untuk dapat tercapainya tujuan seksual dan terlindungnya diri dari aktivitas seksual yang tidak diinginkan atau tidak aman. Penelitian menemukan bahwa remaja putri lebih berisiko dibandingkan dengan remaja putra dalam ketidakmampuan menolak perilaku seksual pranikah dan melawan pasangan untuk membela diri sendiri (Davis, 2008). Jika remaja putri mampu 
melakukan pertimbangan terhadap perilaku seksual pranikah, dimana pertimbangan tersebut akan memunculkan pemahaman tentang resiko perilaku seksual, maka remaja putri akan mampu untuk mengelola dorongan seksualnya secara baik dan dorongan seksualnya dapat disalurkan secara sehat serta bertanggungjawab (Falah, 2009).

Menurut penelitian Nasri dan Koentjoro (2015) peningkatan asertivitas dapat mencegah perilaku seksual pada remaja, dimana remaja akan lebih memahami bahwa dirinya memilki hak yang sama untuk mengungkapkan perasaan dan pendapat dengan cara yang positif, sehingga akan mengurangi tekanan negatif yang mempengaruhi individu dalam hal pengambilan keputusan, termasuk dalam melakukan perilaku seksual. Oleh karena itu, diperlukan tindakan untuk mencegah dan mengurangi perilaku seksual pranikah pada remaja putri di SMK Baabul Kamil Jatinangor. Hal tersebut dapat terwujud dengan melakukan pendidikan kesehatan mengenai pencegahan perilaku seksual melalui peningkatan asertivitas pada remaja putri.

\section{Metode}

Metode yang digunakan dalam kegiatan Pengabdian pada Masyarakat ini adalah dengan pendidikan masyarakat dalam bentuk ceramah, tanya jawab, dan demonstrasi. Remaja putri di SMK Baabul Kamil berjumlah 98 orang tetapi yang dapat dijangkau dalam pelaksanaa pendidikan kesehatan ini berjumlah 65 orang. Sebelum dilakukan penyuluhan, penyuluh terlebih dulu menanyakan pemahaman siswa mengenai perilaku seksual. Penyuluhan dilaksanakan diruang kelas dengan durasi waktu 25 menit dimana selama 10 menit untuk pemaparan materi dan 15 menit untuk diskusi bagi peserta yang ingin mengajukan pertanyaan. Kemudian, dilakukan evaluasi singkat dimana penyuluh mengajukan 3 pertanyaan kepada peserta.

Adapun rincian materi perilaku seksual seperti definisi, tahapan perilaku seksual dalam pacaran, dan dampak dari perilaku seksual pranikah. Kemudian, materi asertivitas seksual yaitu terkait bagaimana menerapkan asertivitas seksual. Pertama, menghormati hak-hak orang lain dan diri sendiri terkait seksual, seperti tidak takut mengutarakan pendapat kepada pacar terkait batasan aktivitas seksual dalam pacaran walaupun usia pacar jauh lebih tua dan tidak takut menolak ajakan pacar dalam melakukan aktivitas seksual. Kedua, berani mengemukakan pendapat secara langsung 
terkait seksual, seperti menyampaikan pendapat dan penjelasan secara tegas kepada pacar dalam aktivitas seksual.

Ketiga, Jujur terkait seksual, seperti selalu berkata jujur saat merasa setuju atau tidak setuju dengan pendapat pacar terkait seksual dan tidak menyembunyikan apapun dalam pacaran termasuk dalam hal seksual. Keempat, memperhatikan situasi dan kondisi terkait seksual, seperti selalu menimbang terlebih dahulu apakah waktu dan situasi tepat untuk membicarakan perihal seksual dengan pacar dan apabila belum saatnya maka tidak dilakukan. Kelima, memperlihatkan bahasa tubuh yang sesuai terkait seksual, seperti menampakkan wajah marah dan mengambil posisi berdiri ketika pacar memaksa untuk melakukan aktivitas seksual.

\section{Hasil}

Dari hasil penyuluhan yang telah dilakukan, sebelum diberikan pemberian materi mengenai perilaku seksual, sebagian besar peserta belum mengetahui tentang perilaku seksual dan bentuk-bentuk perilaku seksual. Sebagian besar dari mereka berpendapat bahwa perilaku seksual diwujudkan dalam bentuk sexual intercourse saja. Mayoritas remaja mengetahui bahwa kehamilan merupakan salah satu dampaknya, namun mereka tidak mengetahui dampak dari tiap perilakunya.

Setelah pemberian materi mengenai perilaku seks dan dampaknya, pemateri memberikan materi mengenai pencegahan perilaku seksual yang dapat dilakukan oleh remaja secara sederhana yaitu dengan memberikan pengetahuan terkait asertivitas seksual. Penyuluh terlebih dahulu menanyakan bagaimana jika peserta mendapat ajakan melakukan perilaku seksual pranikah oleh pacar namun sebagian besar dari mereka menunjukkan sikap yang cenderung agresif dan adapula yang bersikap ragu-ragu atau submisif.

Oleh karena itu, penyuluh mencontohkan cara yang tepat untuk menolak jika diajak melakukan perilaku seksual oleh pasangan mereka yaitu dengan asertif. Sebelumnya sebagian besar dari mereka tidak mengetahui terkait asertivitas hanya sebagian kecil yang sudah mengetahui tetapi hanya sebatas komponen menghormati hak-hak orang lain dan diri sendiri yang memang sudah menjadi norma dalam kehidupan sehari-hari sedangkan komponen seperti memperlihatkan bahasa tubuh yang sesuai terkait seksual belum dipahami oleh siswi tersebut. 
Setelah dilakukan pemberian kedua materi, peserta diberi kesempatan bertanya jika dari mereka ada yang ingin bertanya mengenai perilaku dan asertivitas seksual dan dilanjutkan dengan pertanyaan dari penyuluh. Hasil evaluasi menunjukkan bahwa peserta antusias terhadap materi penyuluhan, tidak ada peserta yang meninggalkan tempat penyuluhan sebelum acara berakhir, peserta mengajukan pertanyaan dan menjawab seluruh pertanyaan secara benar.

\section{Pembahasan}

Dengan persepsi remaja yang menganggap bahwa perilaku lainnya selain berhubungan badan adalah bukan perilaku seksual, maka hal ini dapat membuat remaja berfikir bahwa perilaku lainnya tidak akan menimbulkan dampak negatif. Hal ini sejalan dengan penelitian yang dilakukan oleh Kumalasari (2016) yang menyatakan bahwa mereka melakukan perilaku seksual namun tidak mengetahui dampak dari perilakunya tersebut. Adapun bentuk dan tahapan perilaku seksual dikemukakan oleh Mutiara, Maria, dan Karwati (2008) bahwa perilaku seksual dimulai dari berpegangan tangan, berpelukan, necking, meraba bagian tubuh yang sensitif, petting, oral seks, hingga sexual intercourse (Mutiara, Maria, \& Karwati, 2008). Menurut Irawati (dalam Yantiningtyas, 2012) bahwa setiap perilaku seksual yang dilakukan dapat menimbulkan dampak negatif yaitu bermula dari berpegangan tangan dapat menimbulkan remaja ingin mencoba aktivitas seksual yang lainnya hingga berlanjut pada berpelukan yang dapat menimbulkan rangsangan seksual terlebih jika menyentuh daerah erogen sehingga akan menimbulkan dorongan seks yang lebih kuat untuk melakukan perilaku selanjutnya seperti berciuman, meraba bagian tubuh yang sensitif, petting, oral seks, hingga sexual intercourse.

Terdapat sebagian kecil siswi yang sudah mengetahui dan mampu menerapkan perilaku asertif terkait seksual tetapi hanya pada komponen menghormati hak=hak orang lain dan diri sendiri terkait seksual. Hal ini dikarenakan komponen ini bersifat umum dan sudah menjadi norma dalam kehidupan sehari-hari. Oleh karena itu, walaupun tidak pernah mendapatkan pendidikan kesehatan sebelumnya terkait mater tersebut akan tetapi siswi mampu menerapkannya.

Disisi lain, komponen yang paling banyak belum dipahami siswi yaitu komponen memperlihatkan bahasa tubuh yang sesuai terkait seksual. Hal ini 
dikarenakan komponan ini merupakan praktik sehingga sulit diterapkan apabila tidak pernah mendapatkan pendidikan kesehatan atau pelatihan sebelumnya terkait materi tersebut. Sejalan dengan penelitian Harsanti (2012), menyatakan bahwa terdapat pengaruh latihan asertif terhadap perilaku seksual beresiko remaja di SMK Negeri " $X$ " Jember, dimana dengan latihan asertif dapat menurunkan perilaku seksual beresiko pada remaja tersebut.

\section{Simpulan}

Remaja putri di SMK Baabul Kamil Jatinangor sebagian besar pernah berpacaran dan beresiko tinggi untuk melakukan perilaku seksual pranikah dan terkena dampaknya. Berdasarkan kondisi tersebut, perlu adanya strategi khusus untuk mencegah serta mengurangi perilaku seksual baik resiko tinggi maupun rendah pada remaja. Oleh karena itu, remaja SMK Baabul Kamil diberikan penyuluhan mengenai perilaku seksual dan asertivitas seksual. Setelah mendapatkan pendidikan kesehatan ini, peserta mampu mengetahui terkait perilaku seksual dan asertivitas seksual.

\section{Ucapan Terima Kasih}

Penulis mengucapkan terima kasih kepada berbagai pihak yang telah membantu menyelesaikan kegiatan penyuluhan dan penulisan artikel ini, antara lain seluruh dosen dan civitas akademika Fakultas Keperawatan Universitas Padjadjaran yang selalu membantu penulis dalam mempersiapkan rangkaian kegiatan ini, Arief Nurrahim, S.ST selaku Kepala Sekolah SMK Baabul Kamil Jatinangor beserta jajarannya yang telah membantu penulis dalam melaksanakan dan menyelesaikan kegiatan ini, siswi SMK Baabul Kamil Jatinangor yang telah bersedia menjadi peserta kegiatan ini, serta keluarga dan teman-teman yang telah membantu baik dari segi waktu dan tenaga sehingga penulis dapat menyelesaikan penyuluhan dan penulisan artikel ini.

\section{Daftar Pustaka}

Badan Kependudukan dan Keluarga Berencana Nasional [BKKBN]. (2016). Sederet Catatan di Hari Kependudukan Dunia. Jurnal Keluarga, edisi kedelapan. https://www.bkkbn.go.id. Diakses tanggal 23 Januari 2018. 
Badan Pusat Statistik [BPS], Badan Kependudukan dan Keluarga Berencana [BKKBN], Kementerian Kesehatan [Kemenkes], \& ICF International. 2013. Survei demografi dan kesehatan Indonesia 2012 kesehatan reproduksi remaja.

http://kesga.kemkes.go.id/images/pedoman/SDKI-2012-Remaja-Indonesia.pdf. Diakses tanggal 21 desember 2017.

Badan Pusat Statistik [BPS]. 2017. Prevalensi Kekerasan terhadap Perempuan di Indonesia, Hasil SPHPN 2016.

https://www.bps.go.id/pressrelease/2017/03/30/1375/satu-dari-tiga-perempuan-usia-15--64-tahun-pernah-mengalami-kekerasan-fisik-dan-atau-seksual-selama-hidupnya.html. (diakses tanggal 1 Juli 2018).

Barter, C., McCarry, M., Berridge, D., \& Evans, K. (2009). Partner exploitation and violence in teenage intimate relationships. https://www.nspcc.org.uk/inform. Diakses tanggal 10 Oktober 2017.

Davis, A. (2008). Interpersonal and physical dating violence among teens. Oakland: National Council on Crime and Delinquency.

El Jabar Print. (2017). Sedikitnya tujuh pasangan nikah di bawah umur. http://eljabar.com. Diakses tanggal 8 November 2017.

Falah, P. N. (2009). Hubungan antara Perilaku Asertif dengan Perilaku Seksual Pranikah pada Remaja Putri. Skripsi. Program Sarjana Universitas Muhammadiyah Surakarta.

Fathimiyah, Iffa. (2018). Hubungan Harga Diri dengan Perilaku Seksual Pranikah pada Remaja Putri di SMK Baabul Kamil Jatinangor. Skripsi. Program Sarjana Universitas Padjadjaran.

Harsanti, I. P. (2012). Pengaruh Latihan Asertif terhadap Perilaku Seksual Beresiko pada Remaja di SMK Negeri "X" Jember. Skripsi. Program Sarjana Universitas Jember.

Hidayat, A.A.A. (2008). Pengantar Kebutuhan Dasar Manusia: Aplikasi Konsep dan Proses Keperawatan Buku 1. Jakarta : Salemba Medika.

Humas FK Unpad. (2015). SCORA Back To School (SBTS). Fakultas Kedokteran Universitas Padjadjaran. http://fk.unpad.ac.id/. Diakses tanggal 30 April 2018.

Jakubowski, P., \& Lange, A. (1976). Responsible assertive behavior: Cognitive. behavioral procedures for trainers. Champaign, Illinois: Research Press.

Kementerian Kesehatan RI. (2015). Situasi Kesehatan Reproduksi Remaja. Pusat Data dan Informasi Kementerian Kesehatan RI.http://www.depkes.go.id. Diakses tanggal 7 Oktober 2017.

Kementerian Pemberdayaan Perempuan dan Pelindungan Anak [KemenPPPA]. 2017. Waspada Bahaya Kekerasan Pacaran. 
https://www.kemenpppa.go.id/index.php/page/read/31/1669/waspada-bahayakekerasan-dalam-pacaran. (diakses tanggal 1 Juli 2018).

Komnas Perempuan. (2018). Lembar Fakta dan Poin Kunci Catatan Tahunan (CATAHU) Komnas Perempuan Tahun 2018 Tergerusnya Ruang Aman Perempuan dalam Pusaran Politik Populisme. http://komnasperempuan.go.id/file/pdf_file/2018/SIARAN\%20PERS\%202018/Lembar \%20Fakta\%20Catahu\%207\%20Maret\%202018.pdf. Diakses tanggal 28 Juni 2018.

Kumalasari, D. (2016). Hubungan pengetahuan dan sikap dengan perilaku seksual pada siswa SMK. Jurnal Ilmu Kesehatan, 1(1). https://ejournal.stikesaisyah.ac.id. Diakses tanggal 27 Mei 2018.

McKay, M., Davis, M., \& Fanning, P. (2009). Messages: The Communication Skills Books $3^{\text {rd }}$ Ed. Oakland: New Harbinger Publications.

Mutiara, W., Maria, K., \& Karwati. (2008). Gambaran perilaku seksual dengan orientasi heteroseksual mahasiswa kos di Kecamatan Jatinangor-Sumedang. Nursing Journal of Padjadjaran University. http://jurnal.unpad.ac.id. Diakses tanggal 18 November 2017.

Nasri, D., \& Koentjoro. (2015). Pelatihan asertivitas normatif terhadap perilaku seksual pranikah pada wanita bermasalah sebagai upaya preventif. Jurnal Ilmiah Psikologi Terapan, 3(2).

Omarsari, S.D., \&Ratna, D. (2008). Kehamilan pranikah remaja di Kabupaten Sumedang. Jurnal Kesehatan Masyarakat Nasional, 3(2).

Sarwono, S.W. 2016. Psikologi Remaja : Edisi Revisi. Jakarta : Rajawali Pers.

Soetjiningsih, C.H. (2008). Remaja usia 15 - 18 tahun banyak lakukan perilaku seksual pranikah. Disertasi.Electronic Theses \& Dissertations. Universitas Gajah Mada.

World Health Organization [WHO]. (2010). Adolescent pregnancy. http://apps.who.int/iris/bitstream/10665/112320/1/WHO_RHR_14.08_eng.pdf. (diakses tanggal 5 Februari 2018).

Yantiningtyas, I. D. 2012. Studi Tentang Pengetahuan Kesehatan Reproduksi dan Intensi Melakukan Perilaku Seksual Pranikah Pada Mahasiswa Di Universitas Padjadjaran Jatinangor. Skripsi. Program Sarjana Universitas Padjadjaran. 